\title{
Kesantunan Bertutur Mahasiswa dalam Pembelajaran Luring dan Daring Melalui Aplikasi WhatsApp
}

\author{
Ramdani Purnamasari' ${ }^{1}$ Nurmansyah ${ }^{2}$, Ita Fitriati ${ }^{3}$ \\ 1,2,3 STKIP Taman Siswa Bima, Nusa Tenggara Barat, Indonesia \\ E-mail: ramdanipurnamasari5@gmail.com, oklahklobegitu@gmail.com, itafitriati@gmail.com
}

\begin{abstract}
Article Info
Abstract

Article History

Received: 2021-08-20

Revised: 2021-09-10

Published: 2021-10-15

The research is a field research using a qualitative approach with the aim of explaining

(1) the speech patterns of students in realizing politeness strategies in face-to-face conversations and via Whatsapp (2) The use of personal pronoun deixis and social deixis in student speech, and (3) Differences in the influence of communication directly

Keywords:

Speech Politeness; Online Lectures; and via Whatsapp to the realization of the selection of student-speaking politeness strategies. The results showed that the speech patterns of students in learning both offline and online through the Whatsapp application did not experience significant Whatsapp. differences. The difference is seen in the dominance of the pattern formed from the effort to realize politeness in speech. The dominant pattern formed from student speech in offline learning is $(-P)+(-D)+(+R)$ using a frank politeness strategy (STT) while in online learning a pattern is formed $(-P)+(-D)+(-R)$ by using the Negative politeness strategy (SKN). Based on these findings, it is indicated that student speech in offline learning tends to ignore differences in social status as well as distance or intimacy because it maximizes the threat to the face of the interlocutor, while in online learning through whatsapp, students try to respect or save the face of the interlocutor because of differences in social status and distance. Differences in the use of social deixis can be seen in student speech through online learning such as dear mother, beautiful mother, lecturer mother as an effort to close distance or intimacy due to differences in social status.
\end{abstract}

\begin{tabular}{l}
\hline Artikel Info \\
\hline Sejarah Artikel \\
Diterima: $2021-08-20$ \\
Direvisi: $2021-09-10$ \\
Dipublikasi: $2021-10-15$
\end{tabular}

Kata kunci:

Kesantunan Bertutur; Perkuliahan Daring; WhatsApp.

\begin{abstract}
Abstrak
Penelitian ini adalah penelitian lapangan dengan menggunakan pendekatan kualitatif dengan tujuan menjelaskan (1) Pola tuturan mahasiswa dalam merealisasikan strategi kesantunan dalam percakapan tatap muka dan melalui Whatsapp (2) Penggunaan deiksis pronomina persona dan deiksis sosial dalam tuturan mahasiswa, dan (3) Perbedaan pengaruh komunikasi langsung dan melalui Whatsapp terhadap realisasi pemilihan strategi kesantunan bertutur mahasiswa. Hasil penelitian menunjukkan bahwa pola tutur mahasiswa dalam pembelajaran baik secara luring maupun daring melalui aplikasi Whatsapp tidak mengalami perbedaan yang signifikan. Perbedaan tampak pada dominasi pola yang terbentuk dari upaya merealisasikan kesantunan bertutur. Pola dominan yang terbentuk dari tuturan mahasiswa dalam pembelajaran luring yaitu $(-P)+(-D)+(+R)$ dengan menggunakan strategi kesantunan terus terang (STT) sedangkan dalam pembelajaran daring terbentuk pola $(-P)+(-D)+(-R)$ dengan menggunakan strategi kesantunan Negatif (SKN). Berdasarkan temuan tersebut dalam diindikasikan bahwa tuturan mahasiswa dalam pembelajaran Luring cenderung mengabaikan perbedaan status sosial maupun jarak atau keakraban karena memaksimalkan ancaman muka lawan tutur sedangkan dalam pembelajaran secara daring melalui whatsapp, mahasiswa berupaya menghormati atau menyelamatkan muka lawan tutur karena adanya perbedaan status sosial dan jarak. Perbedaan penggunaan deiksis sosial tampak dalam tuturan mahasiswa melalui pembalajran secara daring seperti ibu sayang, ibu cantik, ibu dosen sebagai upaya untuk mendekatkan jarak atau keakraban karena perbedaan status sosial.
\end{abstract}

\section{PENDAHULUAN}

Bahasa sebagai sarana interaksi perlu diperhatikan tindak laku berbahasa. Tindak laku berbahasa harus disertai dengan norma-norma yang berlaku di dalam budaya masyarakat pengguna bahasa [1], termasuk dalam hal ini penggunaan bahasa yang santun. Kesantunan merupakan aturan perilaku yang ditetapkan dan disepakati bersama oleh suatu masyarakat tertentu sehingga kesantunan sekaligus menjadi prasayarat yang disepakati oleh perilaku sosial [7]. Selain itu, Brown dan Levinso [6] memaknai 
kesantunan sebagai usaha penutur untuk menjaga harga diri, atau wajah, penutur atau pendengar. Artinya dalam berbahasa, seseorang harus mampu menghargai mitra tutur, baik dalam konteks tuturan secara langsung (face to face) maupun tidak langsung salah satunya melalui penggunaan aplikasi Whatsapp.

Whatsapp salah satu platform perpesanan secara instan terbesar dengan pengunaan terbanyak, memiliki fitur yang lengkap dan mumpuni [3]. Mulai dari pengiriman dokumen dalam format doc, xls, pdf. Selain itu, ketersedian emotikon-emotikon memungkinkan penggunaannya dapat mengancam atau menyelamtakan muka penutur maupun lawan tutur. Pada masa pandemi Covid -19 , sesuai dengan kebijakan pemerintah melalui surat edaran Direktur Jendral Pendidikan Tinggi nomor 6 Tahun 2020 terkait pembelajaran secara daring [3], maka aplikasi ini menjadi salah satu alternatif yang dapat digunakan agar proses pembelajaran dapat terus terlaksana karena menyediakan fitu-fitur yang cukup mudah diakses oleh dosen maupun mahasiswa.

Persoalan kesantunan berbahasa dapat dikaji dari segi status sosial yang dimiliki oleh individu pengguna bahasa, seperti tingkatan usia, pendidikan, jabatan atau kekuasaan [7]. Penutur maupun lawan tutur perlu mempertimbangkan skala-skala kesantunan sebagai upaya dalam memaksimalkan kesantunan bertutur, diantaranya (1) Power 'Kekuasaan' ditentukan oleh parameter perbedaan usia, jenis kelamin, pendidikan dan kedudukan (+/-P); (2) Distance 'Jarak Sosial' diukur berdasarkan lama atau barunya (akrab dan tidak akrabnya) penutur dan lawan tutur saling mengenal (+/-D); dan (3) Rank 'Situasi Publik' diukur ada tidaknya orang ketiga atau keempat yang ikut mendengar tuturan penutur dengan lawan tutur $(-/+\mathrm{R})$.

Peserta tutur berkepentingan untuk saling menjaga muka masing-masing, terutama karena sejumlah tindak tutur secara alamiah mengharuskan penggunaan strategi kesantunan tertentu untuk mengurangi resiko atau akibat kurang menyenangkan dari tuturannya. Gusnawaty (2017) berpendapat bahwa Strategi kesantunan adalah pilihan strategi yang digunakan oleh penutur untuk menyampaikan maksud (berdasarkan konteks) kepada penutur [5]. Adapun strategi kesantunan yang ditawarkan oleh Brown dan Levinson (1987) diantaranya; 1) Terus Terang (STT) Kesantunan Positif (SKP), 3) Kesantunan Negatif (SKN), 4) Samar-Samar (Sm), dan 5) Diam (Dm). Urutan strategi tersebut menunjukkan bahwa semakin rendah resiko yang dapat ditimbulkan oleh FTA, semakin rendah pula strategi yang digunakan dan begitu pula sebaliknya [7].

Penelitian ini bermaksud untuk menemukan pola tuturan mahasiswa dalam merealisasikan strategi kesantunan dalam tuturan langsung dan melalui Whatsapp, realisasi strategi kesantunan bergantung pada pola tuturan yang terbentuk $(+/-)$, sehingga memungkinkan terjadinya ancaman muka penutur maupun maupun lawan tutur atau sebaliknya. Penelitian ini tentu menarik mengingat bahwa akses komunikasi antara dosen dan mahasiswa menjadi tidak terbatas, dalam artian tidak hanya dibatasi oleh ruang dan waktu saja, informasi-informasi terkait waktu perkuliahan, tugas, diskusi, konsultasi skripsi maupun perizinan, selalu menjadi bagian dari topik perbincangan antara dosen dengan mahaiswa. Oleh karena itu, perlu diteliti lebih lanjut untuk memperoleh pola kesantunan, penggunaan deiksis pronomina serta perbedaan strategi kesantunan yang digunakan mahasiswa dalam pembelajaran luring dan daring melalui aplikasi Whatsapp.

\section{METODE PENELITIAN}

Penelitian ini adalah penelitian lapangan dengan menggunakan pendekatan kualitatif. Mahsun (2013) berpendapat bahwa pendekatan kualitatif mengarah pada fenomena sosial termasuk fenomena kebahasaan serta bertujuan untuk menjelaskan fenomena kebahasaan yang tengah diteliti [6]. Metode yang digunakan pada penelitian ini adalah metode dekriptif analitis. Metode ini dilakukan untuk memperoleh data yang akurat tentang tuturan yang digunakan oleh informan sehingga diperoleh gambaran pola tuturan berdasarkan realisasi strategi kesantunan yang digunakan, sedangkan metode analitis digunakan untuk menganalisis perbedaan pengaruh komunikasi langsung dan melalui Whatsapp terhadap realisasi pemilihan strategi kesantunan bertutur, serta mengidentifikasi penggunaan deiksis persona dan sosial dalam tuturan mahasiswa.

Sumber data penelitian adalah tuturan yang digunakan oleh mahasiswa ketika terlibat percakapan dengan dosen dalam pembelajaran secara luring dan daring melalui Whatsapp, serta data yang memuat identitas informan yang diperoleh melalui wawancara. Teknik pengumpulan data dilakukan dengan menggunakan teknik sadap dengan alat bantu berupa kamera yang di setting dalam bentuk video, 
sedangkan untuk data tuturan dari percakapan via Whatsapp diambil dengan teknik screenshoot (tangkap layar). Selain itu, untuk mengumpulkan data identitas informan digunakan teknik cakap semuka dalam metode cakap [7].

Teknik analisis data dilakukan melalui tiga tahapan diantaranya Tahap reduksi berupa pengelompokkan berdasarkan sumber pemerolehannya, yaitu data tuturan dari hasil percakapan tatap muka dan melalui Whatsapp. Kemudian pengodean yang dilakukan ketika dalam analisis tuturan ditemukan penggunaan starategi kesantunan seperti STT, SKP, SKN, Sm, dan Dm) berdasarkan pertimbangan skala kesantunan seperti $-\mathrm{U} /+\mathrm{U}, \mathrm{Kd} /+\mathrm{Kd},-\mathrm{Pd} /+\mathrm{Pd}$ sehingga diperoleh pola tuturan seperti $\mathrm{Pw} /+\mathrm{Pw},-\mathrm{D} /+\mathrm{D}$ dan $-\mathrm{R} /+\mathrm{R}$. begitu pula dengan penggunaan deiksis pronomina persona, seperti PP1T dan PP1J, PP2T dan PP2J, dan PP3T dan PP3J [2]. Pengklasifikasian data tuturan yang digunakan oleh mahasiswa berdasarkan realisasi pola dan pilihan strategi dalam tuturan mahasiswa. Data tuturan yang telah direduksi disajikan dalam bentuk tabel serta ditarik kesimpulan berdasarkan analisis data dan kesesuaian dengan maksud dan tujuan penelitian.

\section{HASIL DAN PEMBAHASAN}

\section{A. Hasil Penelitian}

Berdasarkan hasil analisis dari data tuturan yang ada, ditemukan pola tuturan mahasiswa baik dalam tuturan langsung maupun melalui Whatsapp, diantaranya (1) $(+P)+(+D)+(+R), \quad(2) \quad(+P)+(-D)+(+R), \quad(3)$ $(+P)+(-D)+(-R), \quad(4) \quad(-P)+(-D)+(+R), \quad(5) \quad(-$ $P)+(+D)+(+R)$, (6) $(-P)+(-D)+(-R)$, dan $(7)(-$ $P)+(+D)+(-R)$ dengan menggunakan tiga strategi kesantunan bertutur yaitu STT, SKP dan SKN. Adapun deiksis pronomina persona serta deiksis sosial yang digunakan di antaranya, (1) penggunaan PP1T saya sebagai rujukan diri, (2) Penggunaan PP2T kamu, mu sebagai rujukan orang kedua tunggal, (3) Penggunaan PP3T -nya untuk menyatakan milik dan PP3T dia. (4) penggunaan PP1J kita, kami sebagai rujukan orang pertama jamak. (5) sistem sapaan dengan menggunakan leksem kekerabatan $i b u / b u / b u k$ sebagai rujukan orang pertama maupun orang kedua tunggal. (6) penggunaan sistem sapaan dengan nama diri sebagai rujukan orang pertama dan kedua tunggal. (7) penggunaan sapaan dengan leksem kekerabatan seperti adinda, anakda sebagai rujukan orang pertama tunggal. (8) sapaan keakraban, sayang, cantik sebagai rujukan orang kedua tunggal. (9) sapaan dengan jabatan seperti dosen sebagai rujukan orang kedua tunggal, dan (10) penggunaan enklitik -ta dalam bahasa Bima (kamu) sebagai rujukan orang kedua tunggal. Realisasi strategi kesantunan dalam tuturan mahasiswa secara langsung dan melalui Whatsapp terdapat perbedaan, mahasiswa cenderung menggunakan STT dalam tuturan langsung, sedangkan tuturan mahasiswa melalui Whatsapp dominan menggunakan SKN. Hal ini mengindikasikan adanya kecenderungan memaksimalkan ancaman muka lawan tutur dengan mengabaikan perbedaan status sosial maupun jarak atau keakraban dari tuturan mahasiswa dalam pembelajaran secara luring dibandingkan dengan tuturan dalam proses pembelajaran secara daring melalui Whatsapp. Selain itu, ketersediaan emotikon seperti:

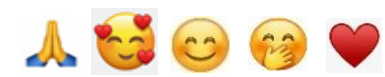

memungkinkan penutur untuk menghormati atau menjaga muka lawan tutur serta mendekatkan jarak/keakraban dengan lawan tutur. Selain itu, kebebasan penutur melalui media tulisan lebih berpeluang memberikan ruang kepada penutur untuk mengungkapkan maksud tuturannya dengan bebas dan terarah.

\section{B. Pembahasan}

1) Pola tutur mahasiswa dalam merealisasikan strategi kesantunan dalam percakapan tatap muka dan melalui Whatsapp

Hasil penelitian meunjukkan bahwa, polapola tuturan yang dihasilkan baik dalam pembelajaran luring maupun daring melalui Whatsapp tidak mengalami perbedaan yang signifikan. Perbedaan hanya tampak pada pola-pola dominan yang muncul berdasarkan realisasi strategi kesantunan, seperti $(-\mathrm{P})+(-$ D) $+(+R)$ dengan menggunakan startegi kesantunan terus terang (STT). Pola tersebut mengindikasikan bahwa, penutur dalam bertutur cenderung mengancam muka lawan tutur dengan mengabaikan perbedaan power $(-\mathrm{P})$ atau status sosial yaitu tingkatan usia, pendidikan serta kedudukan. Selian itu, tampak ada jarak atau tidak terjalin hubungan keakraban antara penutur dengan lawan tutur (-D). Kehadiran orang ketiga (+R) dalam situasi tutur berpotensi mempengaruhi 
keterancaman muka lawan tutur, Seperti pada contoh data berikut:

\section{Data 11 (7 Mei 2021 Pukul: 10.00)}

$\mathrm{M}$ : (datang menghampiri) Bu, saya belum tahu tugas pengganti UAS $t a$ bu, soalnya kemarin mada (saya) nda masuk kuliah.

D: Kenapa nda tanya teman-teman mu?

M: (tersenyum sambil menggaruk kepala)

D: Kamu buat media pembelajaran sesuaikan dengan materi dan tujuan materi yang terdapat dalam RPP B.indo SD

M: iyo ta ibu.

\section{Data 5 (14 Juni 2021 Pukul. 09.20)}

M: Ibu nanti tugasnya dikirm lewat WA?

D: Buat dalam bentuk video baru kirim ke group ya.

M: Siap ibu

Analisis: Percakapan berlangsung dalam proses pembelajaran tatap muka, di ruang kelas dengan topik yang berbeda. Data 11 topik pembicaraan terkait tugas pengganti UTS pada mata kuliah pengembanagn kemampuan berbahasa dan sastra Indonesia SD yang diprogram pada semester IV. Data 5 topik tuturan berkenaan dengan tugas perkuliahan dalam Mata Kuliah Perencanaan Pengajaran yang diprogram pada semester IV. Tuturan 'Ibu nanti tugasnya dikirm lewat WA?' maupun tuturan ' $B u$, saya belum tahu tugas pengganti UAS ta $b u, \ldots$ ' dituturkan penutur (M) secara langsung dan berpotensi mengancam muka lawan tutur (D) karena lawan tutur tidak diberikan kebebasan untuk bertindak melainkan harus merespon tuturan penutur.

Pola lain yang dominan terbentuk dari tuturan penutur $(\mathrm{M})$ baik dalam pembelajaran secara daring melalui Whatsapp yaitu (-P) + (D) $+(-R)$ dengan menggunakan strategi kesantunan Negatif (SKN). Dalam realisasi startegi kesantunan ini, peluang untuk menghormati atau menjaga muka lawan tutur lebih besar karena memperhatikan adanya perbedaan power (-P) berupa status sosial serta mempertimbangkan adanya jarak atau ketidakaakraban $(-\mathrm{R})$ antara penutur dengan lawan tutur. Seperti pada contoh data berikut:

\section{Data 28 (7 Juni 2021 pkl.09.40)}

M: Assalamualaikum mohon maaf menganggu waktu ibu anaknda kirim tugasnya atas nama Arjuna soalnya di kampung dia susah akses jaringan ta ibu jadi anaknda kirim pribadi lembo ade ta ibu. Wasalam
D: Waalaikum salam, baik.

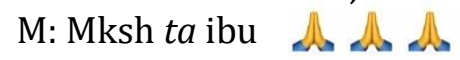

Penutur (M) dalam tuturannya "mohon maaf..." termasuk dalam strategi kesantunan Negatif. Penutur berupaya menyelamatkan muka negatif lawan tutur (D) dengan mempertahankan kebebasan bertindak lawan tutur. Bentuk tuturan tersebut menunjukkan pula adanya jarak sosial antara penutur dengan lawan tutur, seperti pilihan penggunaan leksem Anakda, yang menunjukkan adanya perbedaan usia antara penutur dengan lawan tutur. Biasanya orang yang belum akrab cenderung berhati-hati dalam bertutur karena dikhawatirkan penutur merasa tersinggung atau merasa terbebani dengan permintaan penutur. Penggunann ucapan Terimakasih dimaksudkan sebagai bentuk penghargaan atas bantuan lawan tutur dan semakin diperkuat melalui penguunaan emotikon: $d \wedge d$

Kecenderungan penutur (M) untuk mendekatkan jarak atau keakraban (+D) dengan lawan tutur (D) akibat perbedaan status sosial (-P) terealisasi dalam startegi kesantunan positif (SKP). Hal tersebut biasanya ditandai oleh penggunaan deiksis sosial melalui leksem keakraban seperti sayang, selain itu ketersediaan emotikonemotikon yang menarik sehingga memunculkan spekulatif yang luas dalam memaknai maksud tuturan. Seperti pada contoh data berikut:

\section{Data 15 (18 Maret pukul.09.59)}

M: Assalamualaikum ibu sayang ini Arabia mau nanya tugasnya kita ini dikirim lewat apa ta??

D: Waalaikum salam. Kumpul pekan depan aja bisa pindahkan ke FD atau kalau msh di dlm hp bw kabel data spy bs tersimpan di laptop ibu.

\section{M: baik bu}

Penutur (M) dalam tuturan memperlihatkan upaya pendekatan hubungan atau keakraban dengan lawan tutur (D), seperti dalam tuturan 'ibu sayang ini Arabia...' dalam tuturannya $\mathrm{M}$ berupaya menyelamatkan muka atau menjaga muka positif $\mathrm{D}$ dengan meningkatkan ketertarikan melalui ungkapan yang menarik perhatian lawan tutur, serta ditunjukkan melalui penggunaan emotikon yang memebrikan gambaran suasan hati 
bahagia, penuh cinta sehingga susasan emosional tetap stabil.

Tabel 1. Pola Tutur Mahasiswa

\begin{tabular}{|c|c|c|c|c|c|c|}
\hline \multicolumn{4}{|c|}{ Tuturan langsung } & \multicolumn{3}{|c|}{ Melalui Whatsapp } \\
\hline Topik & $\begin{array}{l}\text { Penutu } \\
\mathrm{r} \& \\
\text { lawan } \\
\text { tutur }\end{array}$ & Pola & SK & $\begin{array}{l}\text { Penutu } \\
\text { r \& } \\
\text { Lawan } \\
\text { tutur }\end{array}$ & Pola & SK \\
\hline Kuis & $\mathrm{D} \rightarrow \mathrm{M}$ & $(+P)+(-D)+(+R)$ & \multirow{3}{*}{ STT } & $M \rightarrow D$ & $(-P)+(-D)+(+R)$ & STT \\
\hline \multirow{2}{*}{ Tugas } & $M \rightarrow D$ & $(-P)+(-D)+(+R)$ & & $M \rightarrow D$ & $(-P)+(-D)+(-R)$ & SKN \\
\hline & $M \rightarrow D$ & $(-P)+(+D)+(+R)$ & & $M \rightarrow D$ & $(-P)+(+D)+(-R)$ & SKP \\
\hline \multirow{3}{*}{$\begin{array}{l}\text { Informa } \\
\text { si } \\
\text { perkulia } \\
\text { han }\end{array}$} & \multirow{2}{*}{$D \rightarrow M$} & $(+P)+(-D)+(+R)$ & $\begin{array}{l}\text { STT \& } \\
\text { SKN }\end{array}$ & \multirow{3}{*}{$\mathrm{D} \rightarrow \mathrm{M}$} & $(+P)+(+D)+(+R)$ & SKP \\
\hline & & $\begin{array}{l}(+P)+(+D)+ \\
(+R)\end{array}$ & STT & & \multirow[t]{2}{*}{$(+P)+(-D)+(+R)$} & \multirow{2}{*}{$\begin{array}{l}\text { SKN \& } \\
\text { STT }\end{array}$} \\
\hline & $M \rightarrow D$ & $(-P)+(+D)+(+R)$ & SKP & & & \\
\hline \multirow{3}{*}{$\begin{array}{l}\text { Izin } \\
\text { perkulia } \\
\text { han }\end{array}$} & \multirow{3}{*}{$M \rightarrow D$} & $(-P)+(-D)+(+R)$ & $\begin{array}{l}\text { STT \& } \\
\text { SKN }\end{array}$ & $M \rightarrow D$ & $(-P)+(-D)+(-R)$ & SKN \\
\hline & & $(-P)+(+D)+(+R)$ & $\begin{array}{l}\text { SKN \& } \\
\text { STT }\end{array}$ & \multirow[t]{2}{*}{$\mathrm{D} \rightarrow \mathrm{M}$} & \multirow[t]{2}{*}{$(+P)+(-D)+(-R)$} & \multirow[t]{2}{*}{ STT } \\
\hline & & $(-P)+(-D)+(-R)$ & STT & & & \\
\hline \multirow{2}{*}{$\begin{array}{l}\text { Informa } \\
\text { si tugas }\end{array}$} & \multirow{2}{*}{$\mathrm{D} \rightarrow \mathrm{M}$} & \multirow{2}{*}{$(+P)+(-D)+(+R)$} & \multirow{2}{*}{ STT } & \multirow{2}{*}{$\mathrm{D} \rightarrow \mathrm{M}$} & $(+P)+(+D)+(+R)$ & SKP \\
\hline & & & & & $(+P)+(-D)+(+R)$ & SKN \\
\hline \multirow{2}{*}{$\begin{array}{l}\text { Keluhan } \\
\text { nilai }\end{array}$} & \multirow{2}{*}{$M \rightarrow D$} & $(-P)+(-D)+(+R)$ & $\begin{array}{l}\text { SKN \& } \\
\text { STT } \\
\end{array}$ & \multirow{2}{*}{$M \rightarrow D$} & \multirow{2}{*}{$(-P)+(-D)+(-R)$} & \multirow{2}{*}{ SKN } \\
\hline & & $(-P)+(+D)+(-R)$ & SKP & & & \\
\hline \multirow{2}{*}{$\begin{array}{l}\text { Bimbing } \\
\text { an } \\
\text { skripsi }\end{array}$} & $M \rightarrow D$ & $(-P)+(-D)+(-R)$ & SKN & $M \rightarrow D$ & $(-P)+(-D)+(-R)$ & SKN \\
\hline & $\mathrm{D} \rightarrow \mathrm{M}$ & $(+P)+(-D)+(+R)$ & STT & & & \\
\hline
\end{tabular}

2) Penggunaan Deiksis Pronomina Persona dan Deiksis Sosial dalam Tuturan Mahasiswa

Penggunaan deiksis pronomina persona dan deiksis sosial dalam tuturan mahasiswa secara langsung melalui whatsapp, tampak adanya perbedaan. Penggunaan leksem keakraban seperti sapaan bu dosen, ibu ku sayang, ibu cantik sebagai rujukan orang kedua tunggal (PP2T) cenderung ditemukan dalam tuturan melalui Whatsapp. Selain itu, penggunaan pronominal persona orang pertama tunggal (PP1T) seperti sebutan nama diri, adinda, anakda seringkali digunakan penutur (M) dalam tuturan melalui Whatsapp. Hal ini mengindikasikan bahwa penutur berupaya menempatkan diri dengan tujuan menghormati serta mendekatkan hubungan atau keakraban dengan lawan tutur. Seperti pada data-data berikut:

\section{Data 25 (16 Juni 2021 pukul. 07.01)}

M: Assalamualaikum buk maaf putri ganggu waktunya pagi2 saya atas nama putri safura dari kls 4 D PGSD pertemuan kali ini nggak bisa hadir bu karna ada adiknya mama yg meninggal

D: waalaikum salam, bâk silahkan list kehadirannya di group dan beri keterangan izin

$\begin{array}{ll}\text { Hasil: } & \mathrm{M} \\ \text { Putri } & \stackrel{+}{\longrightarrow} \text { bu }\end{array}$

\section{Data 29 (6 Juli 2021 Pukul 07.28)}

D: Baru 1 org yg konfirmasi dan nilainya sdh msk, atas nama Nuraini

M1: Makasih banyak ta ibu q sayang

M2: Insya Allah kirim besok ta
Hasil:

$\stackrel{\mathrm{M}}{\longrightarrow} \stackrel{+}{\mathrm{I}} \mathrm{D}$

Data 43 (8 September 2021 Pukul. 10.23)

M: Assalamualaikum. Mohon ijin ibu bisa adinda menghadap di rumahnya bu?

D: skrng sy msh di luar. Sy pembimbing ke berapa?

M: pembimbing kedua ta ibu. Mada (sy) pengen bimbing karoci (cepat) ta bu

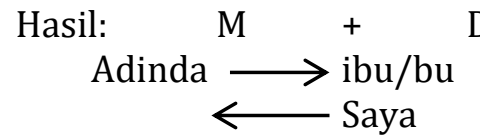

Tabel 2. Deiksis Pronomina Persona dan Deiksis Sosial dalam Tuturan Mahasiswa

\begin{tabular}{|c|c|c|c|c|c|c|c|}
\hline \multicolumn{4}{|c|}{ Tuturan langsung } & \multicolumn{4}{|c|}{ Melalui Whatsapp } \\
\hline $\begin{array}{l}\text { Pro } \\
\text { no } \\
\text { min } \\
\text { a } \\
\end{array}$ & $\begin{array}{l}\text { Perta } \\
\text { ma }\end{array}$ & Kedua & Ketiga & $\begin{array}{l}\text { Pronomi } \\
\text { na }\end{array}$ & $\begin{array}{l}\text { Perta } \\
\text { ma }\end{array}$ & Kedua & Ketiga \\
\hline $\begin{array}{l}\text { Tun } \\
\text { ggal }\end{array}$ & $\begin{array}{l}\text { Saya, } \\
\text { nama } \\
\text { diri }\end{array}$ & $\begin{array}{l}\mathrm{Mu}, \\
\mathrm{ibu}, \\
\mathrm{bu}, t a, \\
\mathrm{mu}, \\
\text { kamu, } \\
\text { nama } \\
\text { diri } \\
\end{array}$ & $\begin{array}{l}\text {-nya, } \\
\text { nama } \\
\text { diri }\end{array}$ & Tunggal & $\begin{array}{l}\text { Saya, } \\
\text { nama } \\
\text { diri. }\end{array}$ & $\begin{array}{l}\text { Bu/ibu/bu } \\
\text { k, ibu } \\
\text { sayang, } t a, \\
\text { ibu cantik, } \\
\text { ibu ku } \\
\text { sayang, } \\
\text { mu, ibu } \\
\text { dosen }\end{array}$ & $\begin{array}{l}\text {-nya, } \\
\text { dia, } \\
\text { nama } \\
\text { diri }\end{array}$ \\
\hline $\begin{array}{l}\text { Jam } \\
\text { ak }\end{array}$ & $\begin{array}{l}\text { Kita, } \\
\text { kami }\end{array}$ & - & - & Jamak & Kita & - & - \\
\hline
\end{tabular}

\section{SIMPULAN DAN SARAN}

\section{A. Simpulan}

Berdasarkan hasil penelitian dapat disimpulkan bahwa, pola tutura mahasiswa dalam pembelajaran luring dan melalui whatsapp tidak mengalami perbedaan yang signifikan. Perbedaan hanya tampak pada pola-pola yang dominan muncul dalam setiap tuturan, yaitu $(-\mathrm{P})+(-\mathrm{D})+(+\mathrm{R})$ dalam merealisasikan strategi kesantunan terus terang (STT) dan pola (-P) + (-D) + (-R) dalam merealisasikan strategi kesantunan Negatif (SKN), sehingga dapat diindikasikan bahwa penutur (mahasiswa) dalam proses pembelajaran secara luring cenderung menggunakan strategi yang mengancam muka lawan tutur, sedangkan dalam pembelajaran daring melalui whatsapp penutur cenderung menghormati atau menjaga muka lawan tutur. Terdapat perbedaan penggunaan pemarkah penanda deiksis oleh penutur. Dalam tuturan melalui Whatsapp ditemukan penggunaan leksem keakraban ibu sayang, ibu cantik, ibu dosen sebagai rujukan orang kedua jamak (PP2T), sebagai upaya untuk mendekatkan jarak atau keakraban karena perbedaan status sosial, termasuk pula penggunaan leksem anakda, adinda, nama diri sebagai rujukan orang pertama Tunggal (PP1T). 


\section{B. Saran}

Adapun saran yang dapat disampaikan berdasarkan hasil penelitian ini yaitu; (1) dosen memaksimalkan perannya terutama dalam pembentukan karakter peserta didik (mahasiswa) melalui pengajaran dan pemberian contoh dalam setiap interaksi, (2) Mahasiswa diharapkan mampu menempatkan diri dalam situasi tutur tertentu agar tercipta interaksi yang mengedepankan etika dan kesantunan, (3) untuk para akademisi, penelitian seperti ini diharapkan dapat dikembangkan misalnya melaui penggumaan aplikasi lain seperti Zoom meeting.

\section{DAFTAR RUJUKAN}

[1] A. Pramujiono and N. Nurjati, "Guru sebagai Model Kesantunan Berbahasa dalam Interaksi Instruksional di Sekolah Dasar," Mimb. Pendidik., vol. 2, no. 2, 2017.

[2] B. K. Purwo, Deiksis dalam bahasa Indonesia. PT Balai Pustaka (Persero), 1984.
[3] Direktorat Jendral Pendidikan Tinggi, Kementerian Pendidikan dan Kebudayaan Republik Indonesia. Surat Edaran Nomor 6 tahun 2020 tentang Penyelenggaraan Pembelajaran tahun akademik 2020/2021

[4] Husna, L. L., \& Arief, E.. Strategi Kesantunan Bertutur Mahasiswa Kepada Dosen Melalui Komunikasi WhatsApp. Jurnal Pendidikan Bahasa dan Sastra Indonesia, 9(4), 13-22, 2020.

[5] L. Gusnawaty and M. Darwis, "Pengakuan dan Etnisitas: Strategi Kesantunan dalam Bahasa Bugis.",2017

[6] Mahsun, Metode Penelitian Bahasa. Jakarta: Rajawali Press, 2013

[7] P. Brown and S. Levinson, Politeness: Some Universals in Language Usage. Cambridge University Press, 1987

[8] P. W. J. Nababan, "Ilmu pragmatik (teori dan penerapannya),” Jakarta: Depdiknas, 1987. 